\title{
Phytochemical and Toxicity Evaluation of Traditional Herb: Lagerstroemia speciosa L. (Banaba) by MCF-7 Cell Line and Brine Shrimp Lethality Bioassay
}

\author{
A.K. Azad ${ }^{1}$, W.S. Azizi ${ }^{2}$, A. F. H. Ismail ${ }^{3}$, Syed Atif Abbas ${ }^{4}$, Jalal Uddin $^{5}$ \\ and Zubair Khalid Labu ${ }^{5}$ \\ ${ }^{1}$ Department of Pharmaceutical Technology, Department of Basic Medical Sciences, Faculty of Pharmacy \\ International Islamic University Malaysia, Jalan Sultan Ahmad Shah, 25200 Kuantan, Pahang, Malaysia \\ ${ }^{2-3}$ Department of Physical Rehabilitation Sciences, Faculty of Allied Health Sciences, International Islamic \\ University Malaysia, Jalan Sultan Ahmad Shah, 25200 Kuantan, Pahang, Malaysia \\ ${ }^{4}$ Faculty of Pharmacy, Quest International University Perak, Malaysia \\ ${ }^{5}$ Department of Pharmacy, World University of Bangladesh, 151/8, Green Road, Dhaka-1205, Bangladesh
}

(Received: August 26, 2018; Accepted: September 20, 2018; Published: January 17, 2019)

\begin{abstract}
The main objective of this study was to determine the cytotoxicity of crude extract of the leaves of Lagerstroemia speciosa (Banaba). In vitro MCF-7 cell line and in vivo brine shrimp lethality bioassay methods were followed to investigate the cytotoxicity of the selected sample. In this study, the qualitative phytochemical assessment demonstrated the presence of alkaloids, carbohydrate, glycosides, saponins, terpenes, steroids, phenols and flavonoids in Banaba extract. Moreover, the present findings revealed the non-cytotoxic nature of $L$. speciosa leaves extract on both MTT-assay and brine shrimp lethality bioassay.
\end{abstract}

Key words: Cytotoxicity, Lagerstroemia speciosa, MCF-7, Brine Shrimp Lethality, MTT.

\section{Introduction}

Banaba (Lagerstroemia speciosa L., crepe myrtle) has been utilized to treat diabetes in different parts of the world, fundamentally Southeast Asia. Banaba, distinguished logically as Lagerstroemia, is a blooming tree that is local to the Malaysia, Philippines and India. The plant can be developed in any atmosphere (Azad et al., 2015). It has been used as a folk medicine since ancient era among in the Philippines for the treatment of diabetes (Stohs et al., 2012). The first published research study reported in 1940 indicated that the pure corosolic acid has been found to decrease blood sugar levels within $60 \mathrm{~min}$ in human subjects. Corosolic acid, isolated from Banaba, also exhibited anti-hyperlipidemic (Garcia et al., 1940), anti-diarrhoeal, analgesic (Hossain Fahad, 2015), hepatoprotective (Lad et al., 2011), nephrotoxicity protective (Basha et al., 2013), antioxidant (Saumya et al., 2011), antidiabetic (Suzuki et al., 2001) and alpha-amylase inhibitory activities (Hosoyama, 2003). Corosolic acid (CA), contained in the leaves of $L$. speciosa, is a pentacyclic triterpene, and has hypoglycemic effects. It has some direct effects on the cholesterol absorption process in the small intestine. It may inhibit the activity of cholesterol acyltransferase, which acts in the re-esterification of cholesterol in the small intestine, in type-2 diabetes (Stohs et al., 2015). Based on previous reports and traditional claim, it has many potential therapeutic effects but unfortunately, no toxicity study was performed. Therefore, it was necessary to investigate the toxicity of this commonly consumed extract in Malaysia and rest of the countries. The present study investigated and found

Correspondence to: W.S. Azizi; Email: drwanazizi@iium.edu.my 
its non-toxic activity in MCF-7 cell line and brine shrimp lethality bioassay methods.

\section{Materials and Methods}

Collection and identification of plant material: The fresh and mature leaves of L. speciosa (15-20 $\mathrm{cm})$ were collected from IIUM Kuantan Campus areas, Indera Mahkota, Kuantan-25200, Malaysia in the month of February-March, 2012. It was authenticated at the Department of Pharmaceutical Chemistry, Faculty of Pharmacy, IIUM with a voucher specimen no. PIIUM: 0423.

Preparation of ethanol extract: For the extraction process, matured leaves of $L$. speciosa were identified, collected and shade dried up to 7-12 days taking care to avoid direct sunlight contact. Then, the leaves were crushed into fine powder by blender. The sieving was done repeatedly to remove the coarse parts. Defatting was done by immersing the leaf powder into petroleum ether for more than 12 hours with regular shaking and stirring. The defatted marc was used for extraction with ethanol. The ethanol extract was concentrated in vacuo (temperature at $45^{\circ} \mathrm{C}, 175$ mbar and rotation $80-85$ rpm) using a rotary vacuum evaporator (BUCHI R205) to a final volume of $500 \mathrm{ml}$. This was further frozen at $-70^{\circ} \mathrm{C}$ and shifted instantly to three weeks freeze drying at $-50^{\circ} \mathrm{C}$ using bench top freeze dryer (ALPHA 1-4LD-2) to give a dry powder (Azad et al., 2015).

Percentage of yield determination: The extract was kept in the fridge $\left(4^{\circ} \mathrm{C}\right)$ from which aliquots were withdrawn for the test. The yield of extract was determined by the final extract weight over the dried plant powder.

Qualitative phytochemical screening of crude extract of $L$. speciosa: The extract was evaluated by standard phytochemical screening of different constituents to detect the presence or absence of secondary metabolites, such as alkaloids, carbohydrates, saponins, amino acids, phytosterols, phenols and flavonoids (Azad et al., 2016; Trease and Evans, 2008).
Brine shrimp lethality bioassay: Thirty-eight gram sea salt was weighed, dissolved in $1 \mathrm{~L}$ of distilled water, adjusted to $\mathrm{pH}-8.5$ using $1 \mathrm{~mol} / \mathrm{l}$ $\mathrm{NaOH}$ and filtered off with cotton plug to get a clear solution (Asaduzzaman et al., 2015). Twenty milligrams of the test sample was dissolved in 200 $\mu \mathrm{L}$ pure dimethyl sulfoxide (DMSO) to give a crude extract concentration of $20 \mathrm{mg} / \mathrm{ml}$ and two fold serial dilution $(250-1.95 \mu \mathrm{g} / \mathrm{ml})$ was carried out with artificial sea water and $2.5 \mathrm{ml}$ of the sample solution was added. After $24 \mathrm{hrs}$, the test tubes were inspected using a magnifying glass and the number of surviving nauplii was counted in each tube. Two types of control groups were used in the present study, distilled water as normal control and $0.1 \%$ DMSO as positive control.

MTT-assay procedure: MCF-7 cells were cultured in $25 \mathrm{t}$-flasks and were maintained in Dulbecco's modified Eagle's medium supplemented with $100 \mathrm{IU} / \mathrm{ml}$ penicillin, $100 \mu \mathrm{g} / \mathrm{ml}$ streptomycin, $10 \%$ fetal bovine serum at $37^{\circ} \mathrm{C}$ with $5 \% \mathrm{CO}_{2}, 95 \%$ air and complete humidity. They were detached using $0.05 \%$ trypsin/ethylene diamine tetraacetic acid and counted by means of trypan blue and hemocytometer when reached $\sim 90 \%$ confluence and then suspended again at a concentration of $4 \times 104$ cells $/ \mathrm{cm}^{2}$ to add into a 96- well plate (i.e., $250 \mu \mathrm{l} /$ well) via a channel pipette. Some wells were kept cell-free as blanks (i.e., controls) for background absorption and comparison (Azad et al., 2018)

Statistical analysis: The mean results of percentage mortality of the brine shrimp versus the $\log$ of concentrations were plotted using the Microsoft Excel (2010) spreadsheet application, which also formulated the regression equation. Then, it was used to calculate the $\mathrm{LC}_{50}$ values for the test samples.

\section{Results and Discussion}

The ethanol extract of $L$. speciosa leaves extract (Banaba) gave $34.23 \%$ yield from $520 \mathrm{~g}$ of raw fruits and finally it became $178 \mathrm{~g}$ of dry crude extract. The preliminary qualitative phytochemical tests exhibited the presence of various phytochemical groups like 
alkaloids, carbohydrates, glycosides, saponins, terpenes, steroids, phenols and flavonoids (Table 1).

Cytotoxicity test on brine shrimp nauplii (Artemia salina) is considered as an in vivo toxicity experiment. The sample extract was dissolved in
0.1\% DMSO. Therefore, $0.1 \%$ DMSO was used as a vehicle control and potassium dichromate was used as a positive control throughout the experiment. The extract revealed $\mathrm{LC}_{50}$ as shown figure 1 .

Table 1. Qualitative phytochemical analysis of the $L$. speciosa leaf extract.

\begin{tabular}{llll}
\hline Compound types & Test & Positive indication & Results \\
\hline Alkaloids & Meyer's test & White/creamy ppt. & ++ \\
Carbohydrates & Fehling's test & Red precipitate & + \\
Glycosides & Benedict's test & Precipitate & + \\
Saponins & Foam test & Foam & + \\
Terpenoids & Libermann-Burchard's test & Pink-purple colour & ++ \\
Steroids & Salkowski Tests & Red colour & + \\
Phenols & FeCl $_{3}$ test & Dark-green & ++ \\
Protein \& amino acids & Ninhydrin solution & Purple colour & + \\
Flavonoids & Magnesium and hydrochloric acid & Crimson colour & ++ \\
& reduction test & & + \\
\hline
\end{tabular}

$(+)$ indicated the presence/intensity of the phytochemicals group in tested sample.

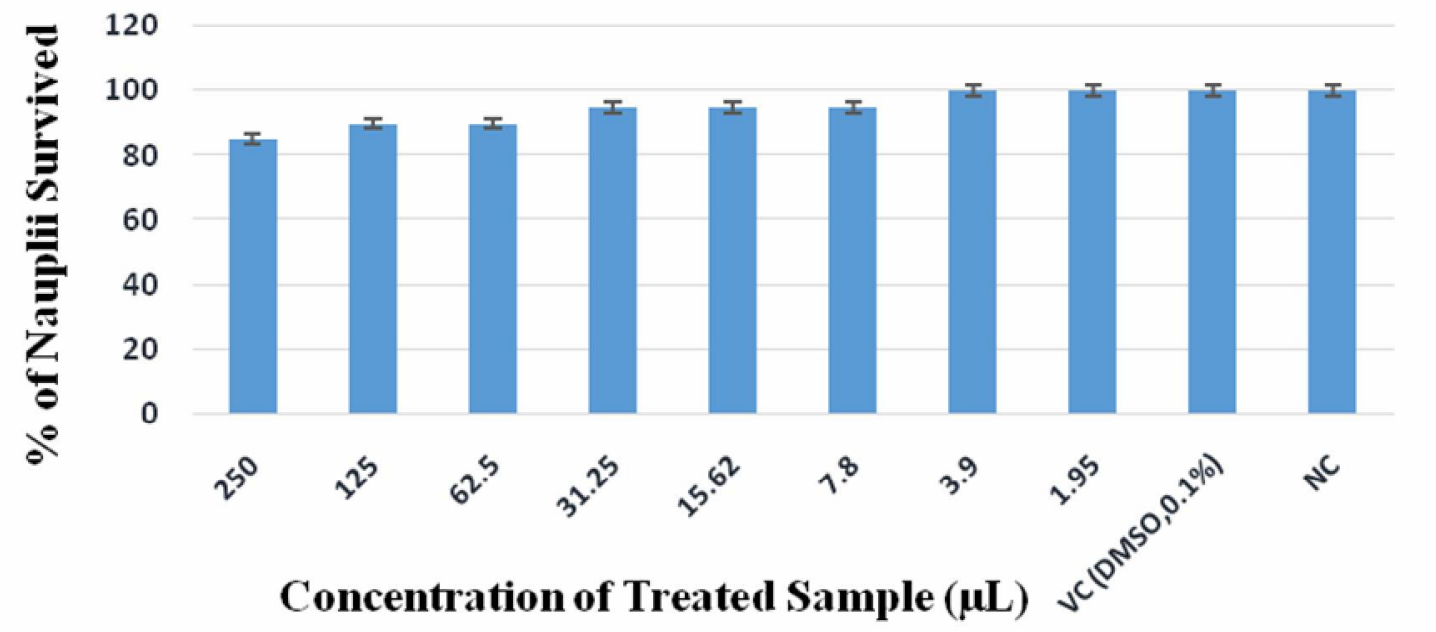

$* \mathrm{VC}=$ Vehicle Control, $\mathrm{NC}=$ Normal Control

Figure 1. The mortality rate $\%$ of brine shrimp nauplii (Artemia salina) at $24 \mathrm{hr}$, after being exposed to various concentrations of $L$. speciosa leaf extract.

In the cytotoxic activity study, the different mortality rate of the naupli was observed in experimental groups, where the survival rate was more than 90 to $95 \%$ at the concentration range of from 7.8 to $125 \mu \mathrm{l}$ and the mortality rate was very negligible until the concentration of $250 \mu \mathrm{l}$. The tested sample concentration of 7.8 and $15.62 \mu \mathrm{l}$ exhibited the same percentage of cell viability with equal standard bar as well. Interestingly, the concentration of $3.9 \mu \mathrm{l}$ and $1.95 \mu \mathrm{l}$ showed $100 \%$ survival rate which was really noticeable (Figure 1). This result indicated that the extract is nontoxic. 
The MTT-assay results showed that the highest percentages of cell viability was $96.0 \%$ at concentration of $1.95 \mu \mathrm{l}$ and the lowest percentage was $88.0 \%$ at concentration of $250 \mu \mathrm{l}$. However, rest of the concentration $(3.9,7.8$ and $15.62 \mu \mathrm{l})$ showed almost $95 \%$ of cell viability. The overall results from in vitro MCF-7 cell line showed that the ethanol extract was non-toxic at the range of the concentration of from 1.95 to $250 \mu \mathrm{l}$ when compared with normal control and vehicle control (1\% DMSO, Figure 2).

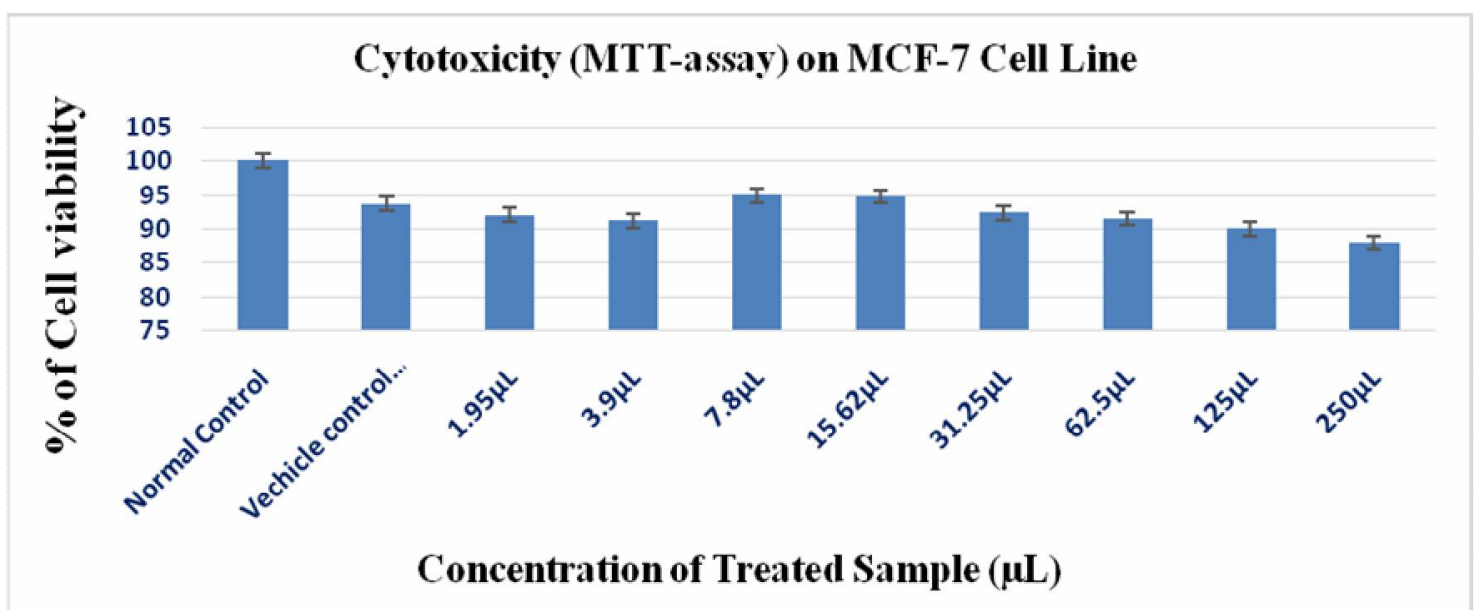

Figure 2. Percentage of cell viability at different concentration of L. speciosa leaf extract using MTT-assay.

\section{Conclusion}

The present study suggested that the crude ethanol extract of Banaba is non-toxic and well tolerated at the tested dose levels. It could be used for further experiment in animal or cell-line studies to determine its level of extended.

\section{References}

Asaduzzaman, M., Sohel Rana, D.M., Raqibul Hasan, S.M., Monir, H.M. and Das, N. 2015. Cytotoxic (brine shrimp lethality bioassay) and antioxidant investigation of Barringtonia Acutangula (L.). Int. J. Pharma. Sci. Res. 6, 1179-1185.

Azad, A. K., Rahman, M. K. and Sunzida, N. K. 2015. Acute oral toxicity study on Malaysian traditional herb: Lagerstroemia speciosa L. (Banaba). $J$. Pharmacogn. Phytochem. 4, 228.

Azad, A. K., Sulaiman, W. M. A. W. and Sunzida, N. K. 2016. Phytochemical and toxicity evaluation of Phaleriamacrocarpa (Scheff.) Boerl by MCF-7 cell line and brine shrimp lethality bioassay. J. Coast. Life Med. 4, 45-49.
Azad, A. K., Jainul, M. A. and Labu, Z. K. 2018. Cytotoxic Activity on Brine Shrimp, MCF-7 Cell line and thrombolytic potential: Seven different medicinal plant leaves extract. J. Sci. Res. 10, 175-185.

Basha M. P. and Saumya S.M. 2013. Influence of fluoride on streptozotocin induced diabetic nephrotoxicity in mice: Protective role of Asian ginseng (Panax ginseng) \& banaba (Lagerstroemia speciosa) on mitochondrial oxidative stress. Ind. J. Med. Res. 137, 370.

Garcia, F. 1940. On the hypoglycemic effect of decoction of Lagerstroemia speciosa leaves (banaba) administered orally. J. Phil. Is. Med. Assoc. 20, 395402.

Hussain, F. 2015. Analgesic and anti-diarrhoeal activities of Lagerstroemia speciosa roots in experimental animal model. Dhaka Uni. J. Pharm. Sci. 13, 57-62.

Hosoyama, Hirokazu. 2003. Isolation and quantitative analysis of the alpha-amylase inhibitor in Lagerstroemia speciose (L.) Pers. (Banaba). Yakugakuzasshi: J. Pharm. Soci. Jap. 123, 599-605. 
Krishnaraju, A. V., Rao, T. V., Sundararaju, D., Vanisree, M., Tsay, H. S. and Subbaraju, G. V. 2006. Biological screening of medicinal plants collected from Eastern Ghats of India using Artemia salina (brine shrimp test). Int. J. Appl. Sci. Eng. 4, 115-125.

Lad P.N., Patel N.C., Shah V.N. and Mesariya P.S. 2011. Evaluation of hepatoprotective and antioxidant activity of roots of Lagerstroemia speciosa Pers. Int. J. Pharm. Res. Dev. 3, 110-117.

Meyer, B. N., Ferrigni, N. R., Putnam, J. E., Jacobsen, L. B., Nichols, D. J. and McLaughlin, J. L. 1982. Brine shrimp: a convenient general bioassay for active plant constituents. Planta Mmed. 45, 31-34.

Padmaja, R., Arun, P.C., Prashanth, D., Deepak, M., Amit, A. and Anjana, M. 2002. Brine shrimp lethality bioassay of selected Indian medicinal plants. Fitoterapia. 73, 508-510.

Ramachandran, S., Vamsikrishna, M., Gowthami, K. V., Heera, B. and Dhanaraju, M. D. 2011. Assessment of cytotoxic activity of Agave cantula using brine shrimp (Artemiasalina) lethality bioassay. Asian J. Sci. Res. 4, 90-94.
Stohs S.J., Howard M. and Gilbert Kaats R. 2012. A review of the efficacy and safety of banaba (Lagerstroemia speciosa L.) and corosolic acid. Phy. Res. 26, 317-324.

Saumya S.M. and Basha Mahaboob, P. 2011. Antioxidant effect of Lagerstroemia speciosa Pers (Banaba) leaf extract in streptozotocin-induced diabetic mice. Ind. J. Exp. Biol. 49, 125-131.

Suzuki, Y., Hayashi, K., Sakane, I. and Kakuda, T. 2001. Effect and mode of action of banaba (Lagerstroemia speciosa L.) leaf extracts on postprandial blood glucose in rats. J. Japan Soc. Nutr. Food Sci. 54, 131137.

Silva, T. M. S., Nascimento, R. J. B., Batista, M. M., Agra, M. F. and Camara, C. A. 2007. Brine shrimp bioassay of some species of Solanum from Northestern Brazil. Rev. Bras. Farmacogn. 17, 35-38.

Trease, G.E. and Evans, W.C. 2008. Pharmacognosy. 5th ed. Revised with the assistance of Daphne Evans. Elsevier Publishers, Netherlands, pp. 488-492.

Tiwari, P., Kumar, B., Kaur, M., Kaur, G. and Kaur, H. 2011. Phytochemical screening and extraction: a review. Int. Pharm. Sci. 1, 98-106. 